\title{
Selection of Reference Genes in Transcription Analysis of Gene Expression of the Mandarin Fish, Siniperca chuasti
}

\author{
ZHOU Rui-Xue ${ }^{1,2}$, MENG Tao ${ }^{1,2}$, MENG Hai-Bo ${ }^{1}$, CHENG Dun-Xue $^{1}$, BIN Shi-Yu ${ }^{2}$, CHENG Jia $^{1}$, \\ FU Gui-Hong, CHU Wu-Ying ${ }^{1, *}$, ZHANG Jian-She ${ }^{1, *}$ \\ (1. College of Biological Engineering and Environmental Sciences, Changsha University, Changsha 410003, China; \\ 2. College of Life Science, Guangxi Normal University, Guilin 541004, China)
}

\begin{abstract}
At present, transcription analysis of gene expression commonly uses housekeeping genes as control for normalization. In this study, the expression levels of three housekeeping genes including GAPDH, $\beta$-actin, and $18 S$ rRNA in six tissues and five developmental stages of the Mandarin fish Siniperca chuatsi were assayed with quantitative real-time PCR (qPCR). Differences in expression levels were analyzed using geNorm program. The results demonstrate that $\beta$-actin is the most stable gene at developmental stages and GAPDH is the most stable in different tissues. While $18 \mathrm{~S}$ rRNA expression during development is differentially regulated, which indicates it is suitable as an internal control for gene expression normalization at the developmental level. Overall, the data suggest that the two most stable housekeeping genes are enough to accurately calibrate gene expression in S. chuatsi. The significance of this study provided convincing references and methodology for housekeeping gene selection and normalization in gene expression analysis with regular PCR or qPCR.
\end{abstract}

Key words: Reference genes; geNorm program; Gene expression; Real-time PCR

\author{
鳜鱼基因表达转录分析中的内参选择比较 \\ 周瑞雪 ${ }^{1,2}$, 蒙 涛 ${ }^{1,2}$, 孟海波 ${ }^{1}$, 陈敦学 ${ }^{1}$, 宾石玉 ${ }^{2}$, 成 嘉 $^{1}$, \\ 符贵红 ${ }^{1}$ ，褚武英 ${ }^{1, *}$ ，张建社 ${ }^{1, *}$ \\ (1. 长沙大学 生物工程与环境科学系, 湖南 长沙 410003; 2.广西师范大学 生命科学学院, 广西 桂林 541004) \\ 摘要：目前基因表达的转录分析多采用单一或多个看家基因作为内参来校正目的基因的表达量。该实验以鳜 \\ 鱼6个不同组织和 5 个不同胚胎发育阶段为研究对象，应用实时荧光定量PCR技术，观察了 GAPDH、 $\beta$-actin和 $18 S$ \\ rRNA三个看家基因mRNA水平的表达情况。geNorm统计分析表明, 胚胎发育阶段 $\beta$-actin表达最为稳定; 不同的组 \\ 织样品间, GAPDH表达最为稳定; 而18S rRNA 的表达在不同的发育阶段不稳定。当利用多基因作为内参时, 使 \\ 用两个最稳定表达的看家基因即可对目的基因的表达进行准确校正。该结果证实了基因表达转录分析中内参基因 \\ 选择的必要性, 同时为鲀鱼等鱼类基因表达分析时内参基因的选择提供有价值的参考。
}

关键词: 内参基因; geNorm程序; 基因表达; 实时定量PCR

中图分类号: Q344.13;Q786;Q959.483 文献标志码: A 文章编号: 0254-5853-(2010)02-0141-06

Real-time PCR (qPCR) technology was first introduced by Applied Biosystems in 1996 and it has been used for quantitative analysis of gene expression based on regular PCR procedures. The principles of
qPCR are to collect fluorescent signals during polymerase reaction cycles and then to accurately determine the gene amplification copies and actual turnout of gene products (Fink et al, 1998; Heid,1996).

Received date: 2009-07-21; Accepted date: 2010-01-18

收稿日期：2009-07-21；接受日期：2010-01-18

基金项目: 国家自然科学基金(30771644;30972263); Aid Program for Science and Technology Innovative Research Team in Higher Educational Instituions of Hunan Province

*通讯作者 (Corresponding authors), E-mail: jzhang@ccsu.cn; chuwuying18@yahoo.com.cn

第一作者简介: 周瑞雪, 女, 广西师范大学研究生, E-mail: numingxue@163.com 
The technology allows sensitive, specific and reproducible quantification of nuleic acids and it has revolutionized the field of molecular diagnostics in a rapidly expanding number of applications ( $\mathrm{Yu}$ et al, 2003). Nowadays, qPCR has been widely applied for analyses on mRNA expression in different organisms, transgenic determination, gene mutation and parasitic organism identification (Ohdan et al, 2005; Ishimaru et al, 2005; Kanegae et al, 2005; Narayanan et al, 2007). The technique has also been used in gene expression analysis of fish. Quantitative data are often normalized to the expression levels of control or so-called "housekeeping" genes such as $\beta$-acitn and Glyceraldehyde-3-phosphate dehydrogenase (GAPDH). An inherent assumption in the use of housekeeping genes is that expression of the genes remains constant in the cells or tissues under investigation. Although exceptions to this assumption are well documented, housekeeping genes are of value in fully characterized systems (Barber et al, 2005). Generally, the variability in the expression levels of commonly used housekeeping genes has meant that there is no "one-size-fits-all" gene that can be used for the normalization of gene expression data. Some researchers suggested that even if a stable internal control gene was chosen, the gene expression level may be variable as its expression could be affected by environmental factors such as nutrition, temperature and oxygen (Liu et al, 2005; Selvey et al, 2001). Therefore, it is crucial to choose a suitable housekeeping gene and to keep a given experimental condition for accurate quantification of gene expression with qPCR.

The Mandarin fish Siniperca chuasti is classified as part of the Osteichthyes, Perciforms, Serranidae and Siniperca Gill families, and is the most commercially important due to their good meat quality (Tang et al, 2007; Fu et al, 2008). Recently, we cloned several muscle-related genes and investigated their expression profile in different tissues and developmental stages (Zhang et al, 2009a,b). From theses studies, we observed that some variations existed in the gene expression quantification if only one housekeeping gene was used for normalization, some controversial conclusions could also occur. Thus, there is a potential significance for a selection of stable expressed housekeeping gene in qPCR application. In this study, three housekeeping genes, $18 \mathrm{~S}$ r-RNA, GAPDH and $\beta$-actin were used to determine mRNA expression in $S$. chuasti in different tissues and various developmental stages using the qPCR technique. Our previous work showed that normal levels for the expression of each gene were defined, and clear differences were observed, which adds values to choose reasonable internal controls on future gene expression analysis in fish.

\section{Materials and Methods}

\subsection{Fish sample collection}

Live $S$. chuatsi of approximately $300 \mathrm{~g}$ body weight were obtained from the culture pond at Hunan Aquaculture Institute, Hunan, China. Tissues of white muscle, red muscle, heart, liver, kidney and spleen were dissected from each fish, with each tissue sample diced into small pieces after washing with physiological water. Samples from different development stages were obtained after artificial fertilization until hatching. Embryos and larvae were cultured in freshwater aquaria at approximately $20^{\circ} \mathrm{C}$ and experimental samples were collected during ontogeny, as described in our previous paper (Zhang et al, 2009ab). All of collected samples were either used immediately for RNA isolation or stored in liquid nitrogen until use.

\subsection{RNA isolation and first strand cDNA synthesis}

Total RNAs was extracted from muscle tissues and embryos. Specifically, $5 \mathrm{~g}$ of frozen samples were homogenized with a hand mortar and then extracted with TRIzolR Reagent (Invitrogen Life Technologies, China) following the standard protocol of the manufacturer. The RNA was then purified on an RNeasy column (Qiagen, China) and stored at $-80^{\circ} \mathrm{C}$ until use. Synthesis of the single-standed cDNA was carried out with the pureExtreme cDNA synthesis kit (Fermentas, USA) according to manufacturer instructions. The reversal transcription was performed using oligo-dT perimers: GGCCACGCGACTAGTAC(T) $)_{16}$.

\subsection{Primer design for $q P C R$}

The primers of the three housekeeping genes, GAPDH, 18SrRNA and $\beta$-actin were designed from the conserved sequences of each gene in Genbank with Primer 5.0 software. The obtained primers (Tab. 1) were synthesized by Shanghai Sangon Biological Engineering Technology \& Service Co. Ltd. The primers were used to determine each housekeeping gene expression at different tissues and developmental stages in S. chuatsi.

\subsection{Quantitative real-time PCR assay procedures}

Real-time PCR was performed using SYBR Green PCR Mix, containing $\mathrm{MgCl}_{2}, \mathrm{dNTP}$, and Hotstar Taq polymerase with the PCR cycler (Stratagene, Mx3005P). $2 \mu \mathrm{L}$ cDNA template was added to a total volume of 25 $\mu \mathrm{L}$ containing $12.5 \mu \mathrm{L}$ SYBR Green mix, and $1 \mu \mathrm{mol} / \mathrm{L}$ 
each of forward and reverse primers. The following protocol was used: (i) pre-denaturation program $(10 \mathrm{~s}$ at $\left.95^{\circ} \mathrm{C}\right)$; (ii) amplification and quantification program, repeated 40 cycles $\left(5 \mathrm{~s}\right.$ at $95^{\circ} \mathrm{C}$ and $20 \mathrm{~s}$ at $\left.60^{\circ} \mathrm{C}\right)$; (iii) melting curve program $\left(60-99^{\circ} \mathrm{C}\right.$ with heating rate of $0.1^{\circ} \mathrm{C} / \mathrm{s}$ and fluorescence measurement). Following reaction completion, samples were kept under $4{ }^{\circ} \mathrm{C}$ until further use.

Tab. 1 Primer sequences for internal control genes

\begin{tabular}{clc}
\hline Housekeeping gene & \multicolumn{1}{c}{ Primer sequence } & Product size (bp) \\
\hline \multirow{2}{*}{ GAPDH } & S: 5'-ATCAAGGAAGCGGTGAAGAAGG-3' & 194 \\
& A: 5'-CGAAGATGGAGGAGTGGGTGTC-3' & \\
\multirow{2}{*}{ 18SrRNA } & S: 5'-GGAATGAGCGTATCCTAAACCC-3' & 180 \\
& A:5'-CTCCCGAGATCCAACTACAAGC-3' & \\
\multirow{3}{*}{-actin } & S: 5'-ATCGTGCGCCCCAGGCACC-3' & \multirow{2}{*}{144} \\
& A: 5'-CTCCTTAATGTCACGCACGATTTC-3' & \\
\hline
\end{tabular}

\subsection{Data analysis}

In order to choose a suitable housekeeping gene, the stability of mRNA expression of each housekeeping gene was statistically analyzed with geNorm software (http://medgen.ugent.be/-jvdesomp/geNorm/).Each PCR experiment consisted of a multiplex reaction in which the expression levels of GAPDH, 18SrRNA, and $\beta$-actin were assayed and the cycle time $(\mathrm{Ct})$ values were accessed from the PCR cycler (Stratagene, Mx3005P) software. The normalized reporter signal for each of the three internal control genes was $<2$. The maximum expression level (the lowest $\mathrm{Ct}$ value) of each gene was used as a control and with an expression amount of 1 . Relative expression levels were then calculated from $\mathrm{Ct}$ values using the formula: $2^{\triangle \mathrm{Ct}}$, in which $\triangle \mathrm{Ct}=$ the minimum $\mathrm{Ct}$ value - each corresponding $\mathrm{Ct}$ value. The obtained data were further analyzed with geNom software to calculate the average expression levels (M) and their variable coefficiency $(\mathrm{V})$ of each gene assayed.

Data were analyzed using Excel (Microsoft) and GraphPad Prism (Prism). Where shown, data correspond to means $\pm S E$. Statistics were performed using one-way

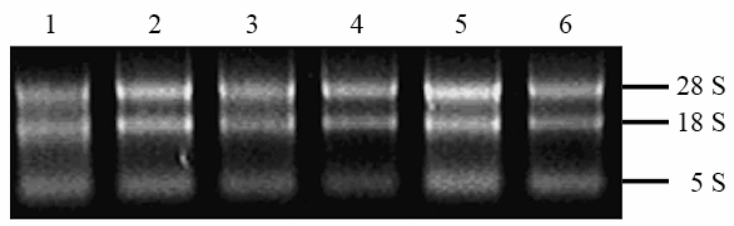

Fig. 1 Electrophoresis examination of total RNAs extracted from different tissues

1: White muscle; 2: Red muscle; 3: Heart; 4: Liver; 5: Kidney; 6: Spleen.

\subsection{Real-time PCR amplification and assay}

To determine the expression of the three internal
ANOVA with post hoc. Data were deemed significant if $P<0.05$.

\section{Results}

\subsection{Determination of RNA concentration and its quality}

RNAs extracted from six tissues and embryos of different developmental stages were diluted to $100 \times$ and their OD values $\left(\mathrm{OD}_{260} / \mathrm{OD}_{280}\right)$ were spectrometrically determined. Purity of the extracted RNAs was double assayed by both the ratio of OD260/OD280 values and $1.0 \%$ agarose gel electrophoresis. As represented in Fig. 1 , each $5 \mu \mathrm{g}$ of total RNAs from six different tissue types including white muscle, red muscle, heart, liver, kidney and spleen were electrophoresed on 1\% agarose gel. Three bands of $5 \mathrm{~s}, 18 \mathrm{~s}$ and $28 \mathrm{~s}$ RNA were uniformly presented. The OD values of the OD260/OD280 ratio of all total RNAs ranged between $1.8-2.1$, which indicates high purity without contamination of other proteins or organic agents. Similar results were also obtained for the RNA gels extracted from five different embryonic stages (Fig.2)

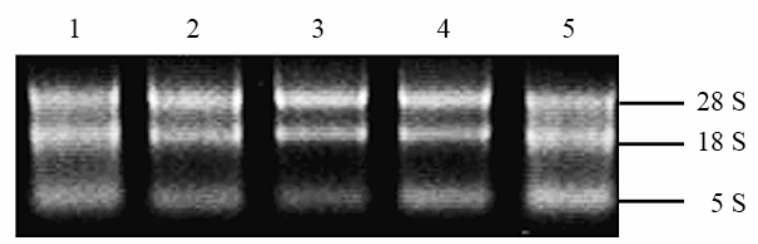

Fig.2 Electrophoresis examination of total RNAs extracted from different developmental stage embryos

1: Gastrula stage; 2: Buds; 3: Muscular effect stage; 4: Cardiac stage; 5: Larval stage.

control genes at mRNA level from different tissues and different embryonic developing stages, a real-time PCR 
technique was applied and their products were analyzed by $1 \%$ agarose gel electrophoresis. The results in Fig. 3 demonstrated that $\beta$-actin was expressed uniformly at all five development stages, but there were some variations for the expression level of both GAPDH and 18SrRNA. Furthermore, expression of the three genes at different tissues was also assayed (Fig. 4). As presented in Fig. 4, 18SrRNA was consistently expressed at six different tissues (lane $1-6$, Fig. 4), $\beta$-actin was abundantly

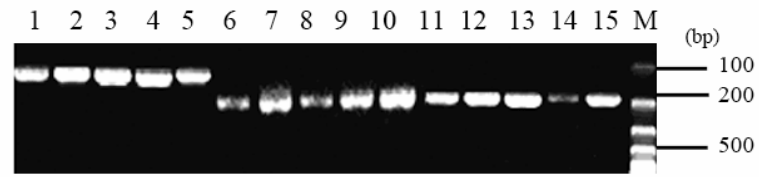

Fig. 3 Electrophoresis examination of differential expression of housekeeping genes from different developmental stage embryos

$1-5$ : the $\beta$-actin; $6-10$ : the GAPDH gene; $11-15$ : 18SrRNA gene; M: DNA Marker. Sample order: Gastrula stage, buds, muscular effect stage, cardiac and larval stage.

genes was analyzed with geNorm program and the average expression level (M) and paired variation coefficient were calculated. As summarized in Fig. 5, the $M$ value of $\beta$-actin from the five different stages was the lowest $(0.233)$, indicating it is most stable. GAPDH is in-between with a $M$ value of 0.2 . While the $M$ value of $18 S$ rRNA was the highest (0.332), which suggests that 18SrRNA expression is developmentally regulated. When assayed at tissue-specific level, the $M$ value of GAPDH of six different tissues was lowest (0.253), indicating its most stably expressed, followed by 18SrRNA (0.265), while $\beta$-actin's expression appeared variable with an $\mathrm{M}$ value at 0.325 (Fig. 6).

When analyzing with geNorm and a set threshold value of 0.15 , if $\mathrm{V}_{n / n+1}<0.15$, it is not necessary to use $\geq n+1$ housekeeping genes as internal control. The resulting data indicate that the paired variable coefficient

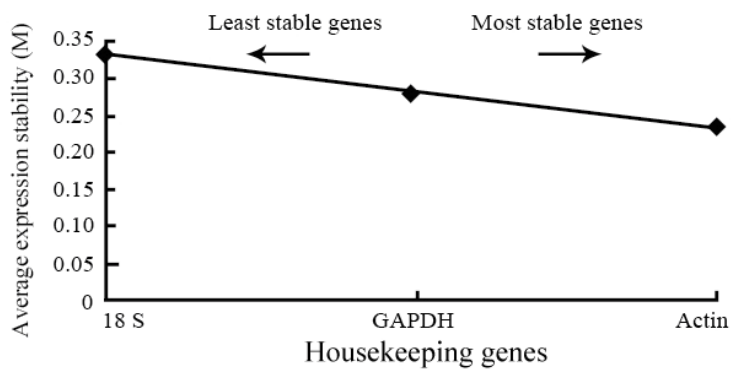

Fig. 5 Average expression stability values of housekeeping genes in different developmental stages analyzed by geNorm expressed at the tissues of white muscle, red muscle, liver and kidney, but less expressed in heart and spleen (lane 7 - 12, Fig. 4), and GAPDH expression appeared constant without obvious variation (Lane $13-18$, Fig. 4).

\subsection{Analysis of expression stability of the three genes}

The expression stability of three housekeeping

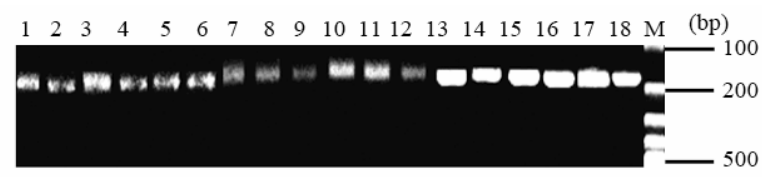

Fig. 4 Electrophoresis examination of differential expression of housekeeping genes from different tissues

1 - 6: 18 S rRNA gene; 7 -12: $\beta$-actin; 13 -18: GAPDH gene; M: DNA Marker. Sample order: White muscle, red muscle, heart, liver, kidney and spleen.

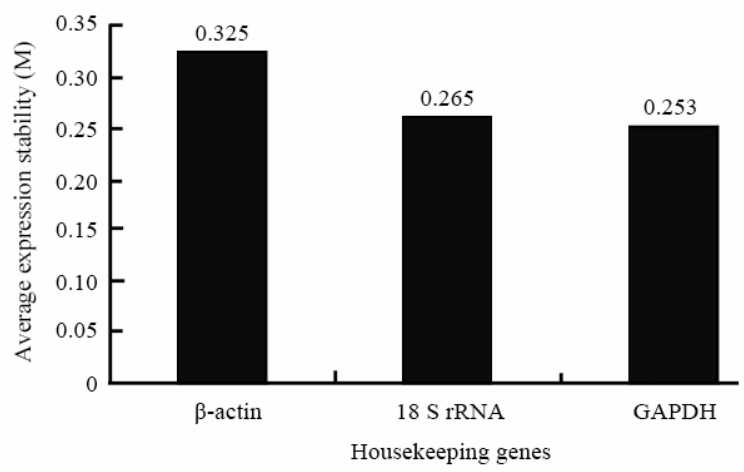

Fig. 6 Average expression stability values of housekeeping genes in different tissues by the geNorm

$\left(\mathrm{V}_{2} / \mathrm{V}_{3}\right)$ from different development stages is 0.132 , while its $V_{2} / V_{3}$ value from different tissues is 0.087 . Both of these values are less than 0.15 , which suggested that two housekeeping genes are optimum for the study.

\section{Discussion}

To quantify the mRNA expression, it is required to calibrate or normalize the data with suitable housekeeping gene. Recent studies have shown that no matter which housekeeping gene (i.e. $\beta$-actin, $18 S$ rRNA, or APDH) is used, expression level could be affected by different experimental conditions, development stages, different tissues or physiological factors, resulting in a potentially biased conclusion (Vandesompele et al, 2002; Radollic et al, 2004; Czechowski et al, 2005). Therefore, it is extremely important to choose one or two suitable housekeeping genes without obvious expression 
fluctuation for gene expression quantification with regular PCR or qPCR technology. Due to relatively constant expression and multiple functions in maintaining of cellular structure, cellular motility, and cell division, $\beta$-actin has been widely selected as internal control (Thellin et al, 1999; Ohdan et al, 2005; Suzuki et al, 2000). However, some studies suggested that $18 \mathrm{~S}$ r-RNA is more stable than $\beta$-actin and it is more applicable as an internal control gene (Selvey et al, 2001). Our work demonstrated that $\beta$-actin expression is the most stable and it is a good calibration gene for the studies on gene expression at developmental level in the $S$. chuatsi. Two other studies reported that $\beta$-actin expression were varied at different tissues in Atlantic salmon (Olsvik et al, 2005; Jorgensen et al, 2006). Our data indicated that $\beta$-actin expression displayed apparent variations from different tissues. Thus, $\beta$-actin is not suitable as an internal control for gene expression quantification at tissue-specific level, at least in fish.

Generally, $18 \mathrm{~S}$ rRNA is quite abundantly expressed in organisms (Deane et al, 2002). Olsvik et al (2005) and Tang et al (2007) assayed tissue-specific expression in Atlantic salmon and Zebrafish (Danio rerio). They confirmed that $18 \mathrm{~S}$ rRNA expression was relatively uniform between tissue types. Similarly, 18SrRNA expression at different tissues in S. chuats was confirmed to be quite stable in this study. However, $18 S$ rRNA's transcription and expression could be affected by some environmental, or physiological factors, or cellular or developmental stages. For example, $28 S$ and $18 S$ RNA become less expressed, even stopped at the interphase of mitosis (Solanas et al, 2001; Chen et al, 2005). Our observation demonstrated that $18 S$ rRNA expression was developmental differentially regulated. Thus, it is not a good internal control for gene expression normalization at developmental level.

Glyceraldehyde 3-phosphate dehydrogenase (GAPDH) is an enzyme that catalyzes the sixth step of glycolysis and thus serves to break down glucose for energy and carbon molecules (Campanella et al, 2005). GAPDH is also one of the most common housekeeping genes and it is often used to normalize gene expression

\section{References:}

Barber RD, Harmer DW, Coleman RA, Clark BJ. 2005. GAPGH as a housekeeping gene: Analysis of GAPDH mRNA expression in a panoll of 72 human tissues[J]. Physiol Genomics, 21: 389-395.

Bustin SA. 2000. Absolute quantification of mRNA using real-time reverse transcription polymerase chain reaction assays[J]. $\mathrm{J} \mathrm{Mol}$ data in real-time PCR assay (Yan et al, 2006). However, there are some disparities with GAPDH as an internal control for gene expression analysis. For example, Bustin (2000) reported that GAPDH appeared unstable during various development stages. However, Olsvik et al (2005) and Tang et al (2007) demonstrated that there are significant differences in the levels of expression of GAPDH mRNA between many tissues. Other researchers have chosen different housekeeping genes as internal controls to obtain an optimum result on gene expression analysis. Cao et al (2005) used 18SrRNA to normalize growth hormone gene expression in extra pituitary tissues of Lepomis cyanellus. Liao et al (2006) assayed the tissue expression of uncoupling protein 2 of silver carp (Hypophthealmichthys molitrx) with $\beta$-actin as an internal control. We have shown that tissue-specific variation of GAPDH mRNA expression levels is generally small, whereas developmental-specific variation of its expression can be substantial.

Theoretically, an ideal housekeeping gene should be relative consistently expressed without much variation with tissues types and development stages (Suzuki et al, 2000). Because of the variations in experimental condition or different cell types, to select one highly stable expressed gene as internal control appeared limited. Vandesompele et al (2002) proposed the use of the geometric mean level of expression from several genes for normalization, and these authors recommended the use of between three and five different control genes, depending on the tissue. Similarly, Schmid et al (2003) argued that analysis of gene expression should be related to several housekeepers in parallel. In fact, in a given experiment, there are some inconveniences and experimental costs if too many internal controls are used ( $\mathrm{Li}$ et al, 2008). The data presented in the present study show that the paired variation coefficient of each house-keeping gene at developmental level is 0.132 , while it is 0.087 at tissue-specific level, and each of them is less than 0.15 , which suggested two housekeeping genes are logic for the gene expression quantification in fish, at least in S. chuatsi.

Endocrinol, 25: 169-193.

Campanella ME, Chu H, Low PS. 2005. Assembly and regulation of a glycolytic enzyme complex on the human erythrocyte membrane[J]. Proc Natl Acad Sci USA, 102 (7): 2402-2407.

Cao YC, Wen HB, Li WS, Lin HR. 2005. The profile of growth 
hormone gene expression in extrapituitary tissues of Lepomis cyanellus[J]. Zool Res, 26(2): 174-178. ( in Chinese)

Chen FH, Wang L. 2005. The choice of reference gene Real-time quantitative RT-PCR[J]. J Clin Lab, 23(5): 393-395.(in Chinese)

Czechowski T, Stitt M, Altmann T. 2005. Genome wide identification and testing of superior reference genes for transcript normalization in Ambid[J]. Plan Physiol, 139(1): 5-17.

Deane EE, Kelly SP, Luk JC. 2002. Chronic salinity adaptation modulates hepatic heat shock protein and insulin like growth factor I expression in black sea bream[J]. Mar Biotechnol, 4(2): 193-205.

Fink L, Seeger W, Ermert L, Hanze J, Stahl U, Grimminger F, Kummer W, Bohle RM. 1998. Real-time quantitative RT-PCR after laser-assisted cell picking[J]. Nat Med, 4: 1329-1333.

Fu GH, Chu WY, Chen J, Liu F, Hu HX, Lu SQ, Xiao DY, Zhang JS. 2008. cDNA cloning and developmental analysis of myosin heavy chain gene in Siniperca keneri[J]. Prog Nat Sci, 11: 1325-1330. ( in Chinese)

Heid CA, Stevens J, Livak KJ, Williams PM. 1996. Real time quantitative PCR[J]. Genome Res, 6: 986-994.

Ishimaru T, Hirose T, Matsuda T. 2005. Expression patterns of genes encoding carbohydrate-metabolizing enzymes and their relationship to grain filling in rice (Oryza sativa L): comparsion of caryopses located at different positions in a panicle[J]. Plan Cell Physiol, 46 (4): 620-628.

Jorgensen S, Kleveland E, Grimholt U, Gjoen T. 2006. Validation of reference genes for real-time polymerase chain reaction studies in Atlantic salmon[J]. Mar Biotechnol ,8: 398-408.

Kanegae H, Miyoshi K, Hirose T. 2005. Expressions of rice sucrose non-fermenting-I related protein kinase I genes are differently regulated during the caryopsis development[J]. Plant Physiol Biochem, 43(7): 669-679.

Li QF, Jing MY, Yu HX, Xin SW, Gu MH, Liu QQ. 2008. Selection of internal reference genes for quantitatiVe RT-PCR analysis of total RNA from endospem of rice[J]. J Yangzhou Univ, 2(29): 61-66.( in Chinese)

Liao WQ, Liang XF, Wang L, Ma X, Fang L, Li GS. 2006. cDNA sequence cloning and tissue expression of uncoupling protein 2 of silver carp (Hypophthealmichthys molitrx)[J]. Zool Res, 27(4): 375-381. ( in Chinese)

Liu DW, Chen ST, Liu HP. 2005. Choice of endogenous control for gene expression in nonsmall cell lung cancer[J]. Eur Respir J, 26(6): 1002-1008

Narayanan NN, Vasconcelos MW, Gmsak MA. 2007. Expression profiling of Oryza sativa metal homeostasis genes in different rice cultivars using a cDNA macroarray[J]. Plan Physiol Biochem, 45(5): 277-286.

Ohdan T, Fmncisco PB, Sawada T. 2005. Expression profiling of genes involved in starch synthesis in sink and source organs of rice[J]. $J$
Exp Bot, 56(422): 3329-3244.

Olsvik PA, Lie KK, Jordal AE, Nilsen TO, Hordvik I. 2005. Evaluation of potential reference genes in real-time RT-PCR studies of Atlantic salmon[J]. BMC Mol Biol, 6: 21.

RadoIlic A, Thulke S, Mackay IM. 2004. Guideline to reference gene selection for quantitative real-time PCR[J]. Biochem Biophys Res Commun, 313(4): 856-862.

Schmid H, Cohen CD, Henger A, Irrgang S, Schlondorff D, Kretzler M. 2003. Validation of endogenous controls for gene expression analysis in microdissected human renal biopsies[J]. Kidney Int, 64: 356-360.

Selvey S, Thompson EW, Atthaei M. 2001. $\beta$-actin an unsuitable internal control for RT-PCR[J]. Mol Cell Probes, 15(5): 307-311.

Solanas M, Moral R, Escfich E. 2001. Unsuitability of using ribosomal RNA as loading control for northern blot analyses related to the unbalance between messenger and ribosomal RNA content in rat mammary tumors[J]. Anal Biochem, 288: 99-102.

Suzuki T, Higgins PJ, Crawford DR. 2000. Control selection for RNA quantitation[J]. Biotechniques, 29(2): 332-337.

Tang JZ, Liu F, Chen J, Zhang DY, Zhang JS. 2007. Comparative analysis of the proteomic profile of the muscle proteins from two teleosts, the Chinese madarine fish and Silver Carp[J]. J Fish Chn, 3: 361-368.

Tang R, Dodd A, Lai D, McNabb WC, Love DR. 2007. Validation of zebrafish (Danio rerio) reference genes for quantitative real-time RT-PCR normalization[J]. Acta Biochim Biophys Sin, 39(5): 384-390

Thellin O, Zorzi W, Lakaye B, De Borman B, Coumans B, Hennen G, Grisar T, Igout A, Heinen E.1999. Housekeeping genes as internal standards:use and limits[J]. J Biotechnol, 75: 291-295.

Vandesompele J, Preter KD, Pattyn F, Poppe B, Van Roy N, De Paepe A, Speleman F. 2002. Accurate normalisation of real time quantitative RT-PCR data by geometric averaging of multiple internal control genes[J]. Genome Biol, 3(7): 1-11.

Yu GL, Jing WY. 2003. Real-time quantitative PCR in the application of medical genetics[J]. Foreign Medical Sciences, 26(3): 125-129.( in Chinese)

Yan HZ, Liou RF. 2006. Selection of internal control genes for real-time quantitative RT-PCR assays in the oomycete plant pathogen Phytophthora parasitica[J]. Fungal Genet Biol, 43(6): 430-438.

Zhang JS, Chu WY, Chen J, Liu F, Liang P, Lu SQ. 2009a. cDNA cloning and expression analysis of myosin heavy chain gene (MHC) of the Mandarin fish, Sniperca kneri[J]. Aquacult Res, 40(4): 412-418.

Zhang JS, Xia XJ, Chu WY, Chen DG, Fu GH, Liu C, Chen J, Liu F, Lu SQ. 2009b. Gene expression profiles of the muscle tissues of the Mandarin fish. Siniperca chuatsi with Zebrafish cDNA microarray[J]. Acta Hydrob Sin, 33(1): 46-53. ( in Chinese) 